\title{
RANCANG BANGUN GAME EDUKASI VOCABULARY ENGLISH MENGGUNAKAN METODE MDLC
}

\author{
Muhammad Rizal $^{1}$, Mursalim ${ }^{2}$, Kamaruddin $^{3}$ \\ Teknik Informatika, STMIK AKBA ${ }^{1,2,3}$ \\ Email :rizal@akba.ac.id¹, mursalim@akba.ac.id²,udin.akba@gmail.com³
}

\begin{abstract}
ABSTRAK
Game Pengenalan nama hewan berbahasa inggris merupakan model pembelajaran yang sangat berpengaruh terhadap proses pembelajaran di sekolah dasar serta penyampaian materi dalam proses kegiatan belajar mengajar. Pada saat anak belajar bahasa inggris secara konvensional maka anak merasa susah memahami materi pembelajaran dan cepat bosan. Pada tahap pendidikan anak usia sekolah dasar, siswa akan cenderung lebih tertarik dengan permainan yang mudah dimainkan dan di dalamnya terdapat warna-warna cerah serta gambar animasi yang menarik perhatian dengan adanya game edukasi sebagai media pembelajaran yang interaktif diharapkan mampu media yang membantu memahami dan menguasai bahasa inggris.Tujuan penelitian untuk membangun game edukasi sebagai media pembelajaran. Metode yang yang digunakan pada penelitian ini yaitu Multimedia Development Life Cylce (MDLC). Hasil penelitian menunjukkan game edukasi pengenalan hewan layak dengan presentasi kelayakan $80,01 \%$ yang digunakan sebagai media pembelajaran.
\end{abstract}

\section{Kata Kunci: Game, Inggris, Hewan}

\begin{abstract}
Game The recognition of animal names in English is a learning model that is very influential on the learning process in elementary schools and the delivery of material in the process of teaching and learning activities. When children learn English conventionally, children find it difficult to understand learning material and get bored quickly. At the elementary school level of education, students will tend to be more interested in games that are easy to play and in which there are bright colors and animated images that draw attention to the existence of educational games as interactive learning media that are expected to be able to media that help understand and master the language english. The purpose of research is to build educational games as learning media. The method used in this research is Multimedia Development Life Cylce (MDLC). The results showed an educational game for animal recognition worthy with a feasibility presentation of $80.01 \%$ which was used as a learning medium.
\end{abstract}

Keywords: Game, English, Animal.

\section{PENDAHULUAN}

Game Pengenalan nama hewan berbahasa inggris merupakan model pembelajaran yang sangat berpengaruh terhadap proses pembelajaran di sekolah dasar serta penyampaian materi dalam proses kegiatan belajar mengajar. Pada tahap pendidikan anak usia sekolah dasar, siswa akan cenderung lebih tertarik dengan permainan yang mudah dimainkan dan di dalamnya terdapat warnawarna cerah serta gambar animasi yang menarik perhatian. Dan dalam tahap ini siswa akan lebih mudah mengingat suatu bentuk atau 
tulisan yang memiliki ciri warna menarik dan bentuk yang komunikatif dan menyenangkan.

Saat ini kebanyakan pembelajaran di sekolah masih menggunakan metode pengajaran buku panduan, begitu pula dengan pembelajaran yang dilakukan di SD Inpres Tabaringan I Makassar. Pada pembelajaran bahasa Inggris, siswa diajarkan bahasa Inggris, dengan materi dasar pengenalan nama hewan yang ada di sekitarnya sesuai dengan kompetensi dasar mengenal jenis dan namanama hewan. Setelah dilakukan observasi di sekolah, dan berdasarkan hasil diskusi dengan guru mata pelajaran bahasaInggris, dapat disimpulkan jika siswa mengalamikesulitan dalam mengenal huruf dan menuliskan urutan huruf untukkata dalam menyebutkan nama hewan. Hal inidapat dilihat pada saat menuliskan urutan huruf untuk menyusun namahewan, banyak terjadi kesalahan, serta hasil nilai ulangan materi pengenalannama hewan dari 38 siswa hanya 9 orangsiswa yang memenuhi nilai KKM yang telah ditentukan. Hal ini disebabkan oleh kurangnya rasa ketertarikan dan kurangnya perhatian siswa untuk mengikuti pembelajaran yang sedang berlangsung. Selain itu materi yang disampaikan tidak dapat diserap dengan baik karena guru masih menggunakan buku cetak. Ketika hal ini terjadi pada tahap pembelajaran dasar siswa akan mengalami kesulitan mengikuti materi-materi pembelajaran selanjutnya. Dengan media pembelajaran game bahasa Inggris ini akan membuat siswa lebih mudah mengingat materi yang disampaikan oleh guru karena disajikan dalam tampilan yang meyenangkan karena menggunakan gambar yang menarik dan huruf sudah tersedia di dalam game tersebut. Dalam game edukasi pengenalan nama hewan ini, siswa akan barmain dengan cara mengurutkan huruf hingga membentuk suatu kata, dengan mengurutkan huruf dan memasukkan ke dalam kotak yang disediakan secara tidak langsung siswa akan merasa terbantu danakan lebih cepat mengingat susunan nama-nama hewan dalam bahasa Inggris.

Berdasarkan masalah yang diuraikan, maka masalah yang akan dibahas pada penelitian ini adalah bagaimana merancang game edukasi vocabulary English menggunakan metode MDLC.

\section{LANDASAN TEORI}

\subsection{Game}

Game adalah sebuah tipe aktivitas bermain, dilakukan dalam konteks berpura-pura, dimana partisipan mencoba untuk mendapatkan setidaknya satu kewenangan, akhir yang tidak mudah dengan bertindak sesuai dengan aturan.(Al-Omari, Shidaifat, \& Dardaka, 2005)

\subsection{Media Pembelajaran}

Media pembelajaran didefinisikan sebagai alat- alat fisik dimana pesan-pesan instruksional dikomunikasikan. Jadi seorang instruktur, buku cetak, pertunjukan film atau tape recorder dan lainlainPeralatan fisik yang mengkomuniasikan pesan instruksional tes untuk mengukur tingkat pemahaman pengguna atas konsep atau materi yang disampaikan.(Arsyad, 2002)

\subsection{Adobe Flash}

Adobe Flash Professional CS6 merupakan software yang mampumenghasilkan presentasi, game, film, CD interaktif, maupun $\mathrm{CD}$ pembelajaran, serta untuk membuat situs web yang interaktif, menarik, dan dinamis. AdobeFlash Professional CS6 mampu melengkapi situs web dengan beberapa macamanimasi, suara, animasi interaktif, dan lain-lain sehingga pengguna sambil mendengarkan penjelasan mereka dapat melihat gambar animasi, maupun membaca penjelasan 
dalam bentuk teks. Adobe Flash Professional CS6 sebagai software untuk pembuatan media pembelajaran interaktif berdasarkan padabeberapa kelebihan yang dimilikinya.(Sutopo, 2003)

\subsection{Multimedia}

Kata- kata, gambar, video, musik, angka, atau tulisan tangan di mana dalam dunia komputer, bentuk informasi tersebut diolah dari dan dalam bentuk data digital. Multimedia adalah kombinasi dari paling sedikit dua media input atau output dari data, media ini dapat audio (suara, musik), animasi, video, teks, grafik dan gambar.Multimedia merupakan alat yang dapat menciptakan presentasi yang dinamis dan interaktif yang mengombinasikan teks, grafik, animasi, audio dan gambar video.(Suyanto, 2005)

\subsection{Metode MDLC}

Pengembangan metode multimedia ini dilakukan berdasarkan enam tahap, yaitu concept (pengonsepan), design (perancangan), material collecting (pengumpulan bahan), assembly (pembuatan), testing (pengujian), dan distribution (pendistribusian. Keenam tahap ini tidak harus berurutan dalam praktiknya, tahaptahap tersebut dapat saling bertukar posisi. Meskipun begitu, tahap concept memang harus menjadi hal yang pertama kali dikerjakan.(Mustika, Sugara, \& Pratiwi, 2018) Gambar 1 adalah gambar tahapan metode MDLC.

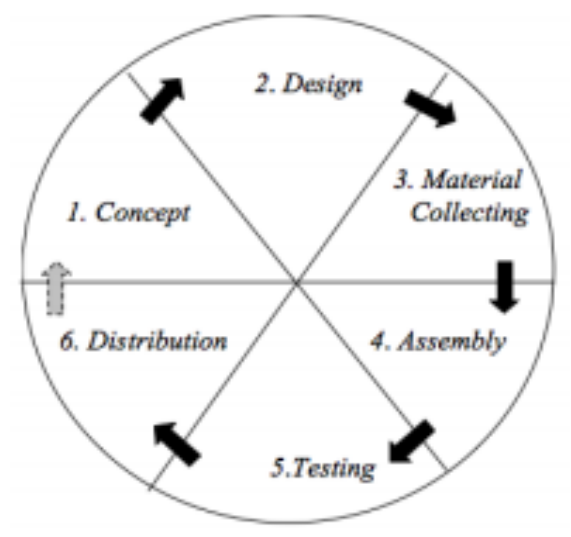

Gambar 1 Metode MDLC
1. Concept (Pengonsepan) Tahap ini adalah tahap untuk menentukan tujuan dan siapa pengguna program (identifikasi audiens). Tujuan dan penggunaan akhir program berpengaruh pada nuansa multimedia sebagai pencerminan dari identitas organisasi yang menginginkan informasi sampai pada pengguna akhir. Pada tahap ini, peneliti melakukan pengonsepan antara lain untuk: a. Menentukan tujuan dan manfaat aplikasi media pembelajaran metodologi manajemen proyek. b. Menentukan siapa saja penguna aplikasi media pembelajaran metodologi manajemen proyek c. Mendeskripsikan konsep aplikasi Media Pembelajaran Interaktif Manajemen Proyek IT yang akan dibangun.

2. Design (Perancangan) Pada tahap ini pembuatan spesifikasi mengenai arsitektur program, gaya, tampilan, dan kebutuhan material / bahan untuk program. Desain yang akan dibuat mengunakan desain interface dari tampilan menu aplikasi. Perangkat lunak yang digunakan untuk merancang interface adalah Microsoft Visio.

3. Material Collecting (Pengumpulan Bahan)

Tahap ini adalah tahap pengumpulan bahan yang sesuai dengan kebutuhan yang dikerjakan. Bahan-bahan tersebut antara lain gambar clip art, foto, animasi, video, audio, dan lain-lain yang dapat diperoleh secara gratis atau dengan pemesanan kepada pihak lain sesuai dengan rancangannya. Tahap ini dapat dikerjakan secara parallel dengan tahap assembly. Namun, pada beberapa kasus, tahap material collecting dan tahap assembly akan dikerjakan secara linear dan tidak parallel. 
4. Assembly (Pembuatan) Tahap assembly (pembuatan) adalah tahap pembuatan semua objek atau bahan multimedia. Pembuatan aplikasi didasarkan pada tahap desain, seperti storyboard, bagan alir, dan/atau struktur navigasi.

5. Testing (Pengujian) Tahap testing (pengujian) dilakukan setelah menyelesaikan tahap pembuatan (assembly) dengan menjalankan aplikasi / program dan dilihat apakah ada kesalahan atau tidak. Tahap pertama pada tahap ini disebut juga sebagai tahap pengujian alpha (alpha test) yang pengujiannya dilakukan oleh pembuat atau lingkungan pembuatnya sendiri. Setelah lolos dari pengujian alpha, pengujian beta yang melibatkan penggunaan akhir akan dilakukan.

6. Distribution (Pendistribusian) Tahap ini aplikasi akan disimpan dalam suatu media penyimpanan. Jika media penyimpanan tidak cukup untuk menampung aplikasinya, kompresi terhadap aplikasinya, kompresi terhadap aplikasi tersebut akan dilakukan. Tahap ini juga dapat disebut tahap evaluasi untuk pengembangan produk yang sudah jadi supaya menjadi lebih baik.

\section{METODE PENELITIAN}

Dalam Pembuatan game edukasi peneliti menggunakan metode Multimedia Development Life Cycle (MDLC). Terdapat 5 tahapan dalam metode MDLC yaitu:

1. Design (Desain/Rancangan). Tahap dimana pembuat menjabarkan secara rinci apa yang akan dilakukan dan bagaimana aplikasi tersebut akan dibuat. Pembuatan naskah ataupun navigasi serta proses desain lain harus secara lengkap dilakukan.
2. Obtaining Content Material (Pengumpulan Materi). Merupakan proses untuk pengumpulan segala sesuatu yang dibutuhkan aplikasi. Mengenai materi yang akan disampaikan, kemudian file-file multimedia seperti audia, video, dan gambar yang akan dimasukkan dalam aplikasi

3. Assembly (Penyusunan dan Pembuatan).Materi-materi sefta file-file multimedia yang sudah didapat kemudian dirangkai dan disusun sesuai desain.

4. Testing (Uji Coba). Setelah hasil dari aplikasi jadi, perlu dilakukan uji coba. sebelum dapat diterapkan pengguna akhir.

5. Distribution (Menyebar Luaskan). Tahap penggandaan dan penyebaran hasil kepada pengguna. Multimedia perlu dikemas dengan baik sesuai dengan media penyebar luasannya, apakah melalui CD/DVD, download, ataupun media yang lain.

\section{HASIL DAN PEMBAHASAN} 4.1 Implementasi Antar Muka

\section{Menu Utama}

Pada tampilan utama utama game terdapat tombol navigasi mulai, aturan main, dan keluar

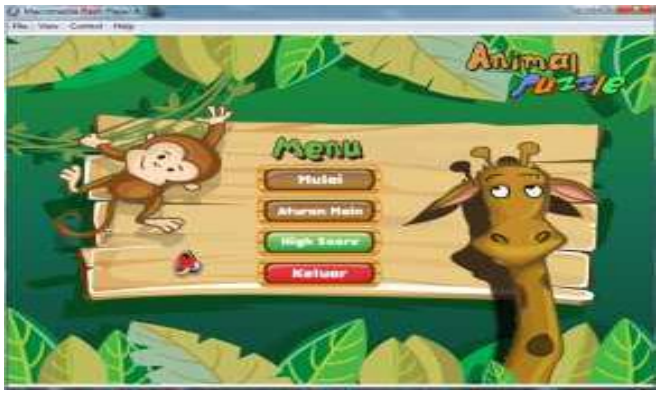

Gambar 2. Menu Utama 


\section{Tampilan Menu Jenis Hewan}

Pada tampilan menu jenis hewan terdapat empat

tombol navigasi yaitu tombol hewan kaki empat, serangga, hewan laut, dan unggas, semua tombol tersebut berfungsi untuk menampilkan soal jenis hewan.

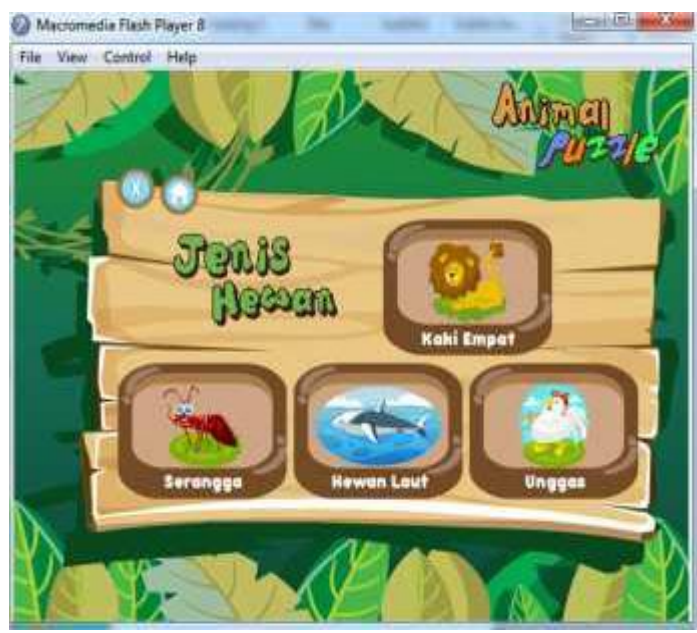

Gambar 3. Menu Jenis Hewan

\section{Tampilan Soal}

Pada tampilan soal terdapat kotak inputan dan huruf acak dalam bahasa inggris. User dapat memasukkan huruf acak tersebut kemudian di urutkan sesuai soal yang ada.

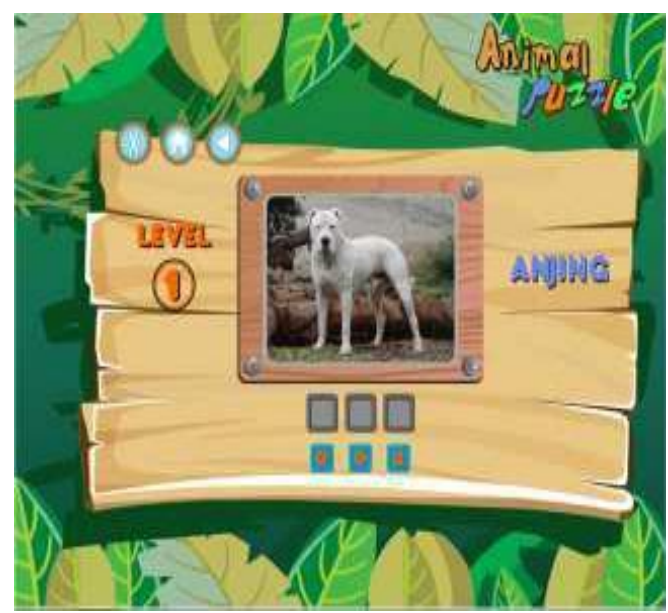

Gambar 4. Tampilan Soal

\section{Tampilan Skor}

Pada tampilan skor terdapat tombol kembali untuk kembali ke menu jenis hewan dan tampilan skor berfungsi untuk menampilkan skor dari soal yang telah di kerjakan oleh user.

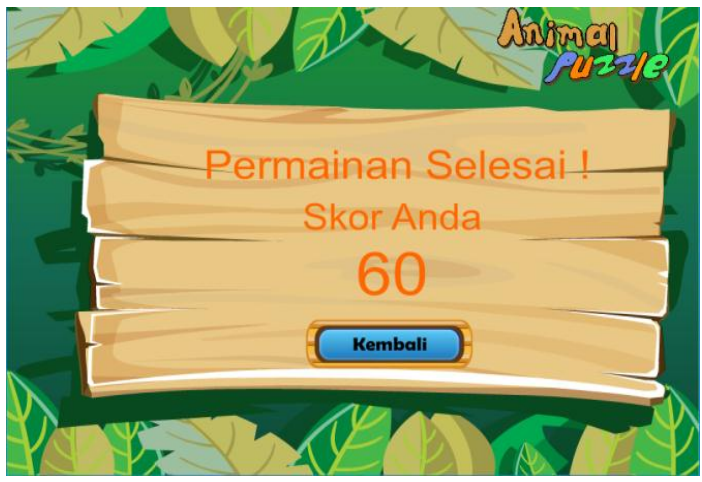

Gambar 5. Tampilan Skor

\subsection{Pengujian User Acceptance}

Setelah setelah game edukasi animal selesai, maka game diujicobakan di lapangan uji coba media ini adalah siswa.

Siswa mencoba aplikasi media yang telah dibuat dan memberikan hasil pengujiandari jumlah 38 siswa dimana 31siswa yang "Tuntas" dan hanya 7 siswa yang "Gagal". Media pembelajaran game edukasi animal ini dilakukan di SDNTabaringan I Makassar Kelas V SD. Instrumen untuk pengguna ditinjau dari aspek pembelajaran, materi, desain tampilan dan pemograman.

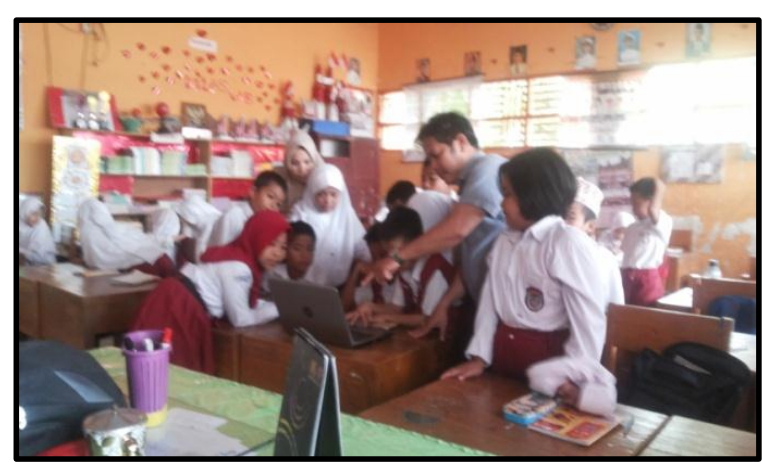

Gambar 6. Pengujian User Acceptance 
Tabel 1. Pertanyaan Pada Kuisioner

\begin{tabular}{ll}
\hline No & \multicolumn{1}{c}{ Pertanyaan } \\
\hline 1 & Kemudahan navigasi \\
2 & $\begin{array}{l}\text { Manfaat navigasi untuk membantu } \\
\text { pengguna }\end{array}$ \\
3 & Ketepatan navigasi yang diinginkan \\
4 & Kemudahan pengoperasian media \\
5 & Keterkaitan gambar dengan materi \\
6 & Penggunaan bahasa mudah \\
& dimengerti \\
7 & Kualitas teks \\
8 & Keterbacaan tulisan \\
9 & Ketepatan ukuran huruf \\
10 & Ketepan warna huruf \\
11 & Ketepatan jenis huruf \\
12 & Kejelasan tata letak gambar \\
13 & Kesesuaian tampilan \\
14 & Kemudahan pemilihan jawaban \\
15 & Ketepatan penggunaan tema \\
16 & Kualitas tampilan desain \\
17 & Kesesuaian warna tulisan dengan \\
18 & Kejelasan petunjuk penggunaan \\
& media pembelajaran \\
\hline &
\end{tabular}

Berdasarkan hasil pengujian game edukasi pengenalan hewan layak dengan presentasi kelayakan 80,01 \% digunakan sebagai media pembelajaran untuk meningkatkan vocabulary English siswa.

\section{SIMPULAN}

Berdasarkan penelitian yang telah dilakukan, maka disimpulkan bahwa aplikasi game edukasi yang telah dirancang membantu para siswa dalam mempelajari bahasa inggris melalui game yang menyenangkan dan menumbuhkan motivasi dalam meningkatkan vocabulary English, dengan tingkat presentasi kelayakan sebesar 80,01\%

\section{DAFTAR PUSTAKA}

Al-Omari, R., Shidaifat, F., \& Dardaka, M. (2005). Castration induced changes in dog prostate gland associated with diminished activin and activin receptor expression. In Life Sciences (Vol. 77). https://doi.org/10.1016/j.lfs.2005.03.030

Arsyad, A. (2002). Media Pembelajaran. Jakarta: PT. Raja Grafindo Persada.

Mustika, M., Sugara, E. P. A., \& Pratiwi, M. (2018). Pengembangan Media Pembelajaran Interaktif dengan Menggunakan Metode Multimedia Development Life Cycle. Jurnal Online Informatika, 2(2), 121. https://doi.org/10.15575/join.v2i2.139

Sutopo. (2003). Multimedia Interaktif dengan Flash. Yogyakarta: Graha Ilmu.

Suyanto, M. (2005). Multimedia Alat untuk Meningkatkan Keunggulan Bersaing. Yogyakarta: Andi Publisher. 